\title{
Circulating Blood-Based Biomarkers in Pulmonary Hypertension
}

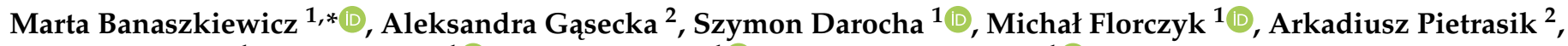 \\ Piotr Kędzierski ${ }^{1}$, Michał Piłka ${ }^{1}{ }^{1}$, Adam Torbicki ${ }^{1}{ }^{\mathbb{D}}$ and Marcin Kurzyna ${ }^{1}{ }^{1}$ \\ 1 Department of Pulmonary Circulation, Thromboembolic Diseases and Cardiology, \\ Centre of Postgraduate Medical Education, European Health Centre Otwock, 05-400 Warsaw, Poland; \\ szymon.darocha@ecz-otwock.pl (S.D.); michal.florczyk@ecz-otwock.pl (M.F.); \\ piotr.kedzierski@ecz-otwock.pl (P.K.); michal.pilka@ecz-otwock.pl (M.P.); adam.torbicki@ecz-otwock.pl (A.T.); \\ marcin.kurzyna@ecz-otwock.pl (M.K.) \\ 2 1st Chair and Department of Cardiology, Medical University of Warsaw, 02-097 Warsaw, Poland; \\ gaseckaa@gmail.com (A.G.); apietrasik@tlen.pl (A.P.) \\ * Correspondence: marta.banaszkiewicz@ecz-otwock.pl
}

check for

updates

Citation: Banaszkiewicz, M.;

Gąsecka, A.; Darocha, S.; Florczyk,

M.; Pietrasik, A.; Kędzierski, P.; Piłka,

M.; Torbicki, A.; Kurzyna, M.

Circulating Blood-Based Biomarkers

in Pulmonary Hypertension. J. Clin.

Med. 2022, 11, 383. https://doi.org/

$10.3390 /$ jcm 11020383

Academic Editors: Dinesh K. Kalra and David Barnes

Received: 30 November 2021

Accepted: 9 January 2022

Published: 13 January 2022

Publisher's Note: MDPI stays neutral with regard to jurisdictional claims in published maps and institutional affiliations.

Copyright: (C) 2022 by the authors. Licensee MDPI, Basel, Switzerland. This article is an open access article distributed under the terms and conditions of the Creative Commons Attribution (CC BY) license (https:// creativecommons.org/licenses/by/ $4.0 /)$.

\begin{abstract}
Pulmonary hypertension (PH) is a serious hemodynamic condition, characterized by increased pulmonary vascular resistance (PVR), leading to right heart failure (HF) and death when not properly treated. The prognosis of $\mathrm{PH}$ depends on etiology, hemodynamic and biochemical parameters, as well as on response to specific treatment. Biomarkers appear to be useful noninvasive tools, providing information about the disease severity, treatment response, and prognosis. However given the complexity of $\mathrm{PH}$, it is impossible for a single biomarker to be adequate for the broad assessment of patients with different types of $\mathrm{PH}$. The search for novel emerging biomarkers is still ongoing, resulting in a few potential biomarkers mirroring numerous pathophysiological courses. In this review, markers related to HF, myocardial remodeling, inflammation, hypoxia and tissue damage, and endothelial and pulmonary smooth muscle cell dysfunction are discussed in terms of diagnosis and prognosis. Extracellular vesicles and other markers with complex backgrounds are also reviewed. In conclusion, although many promising biomarkers have been identified and studied in recent years, there are still insufficient data on the application of multimarker strategies for monitoring and risk stratification in $\mathrm{PH}$ patients.
\end{abstract}

Keywords: pulmonary hypertension; chronic thromboembolic pulmonary hypertension; pulmonary arterial hypertension; biomarkers; right heart failure

\section{Introduction}

Pulmonary hypertension (PH) is a progressive, heterogenous disease, characterized by increased pulmonary vascular resistance (PVR), subsequently leading to elevated pulmonary arterial pressure (PAP) and increased workload of the right ventricle (RV). The RV adapts to the pathological afterload by increasing wall thickness and contractility. However, the compensatory mechanisms may fail, resulting in right heart failure (HF) and death, if not properly treated.

Consistent with the European Society of Cardiology (ESC)/European Respiratory Society (ERS) Guidelines, there are five groups of PH, according to clinical and pathophysiological criteria. Group 1 contains idiopathic pulmonary arterial hypertension (iPAH), as well as drug-induced PAH and all heritable forms of PAH. Group 2 is PH secondary to left-sided heart failure. PH in group 3 is caused by lung disease and/or hypoxia, and group 4 is chronic thromboembolic pulmonary hypertension (CTEPH). Group 5 consists of $\mathrm{PH}$ due to uncertain multifactorial mechanisms. Targeted pharmacological or interventional treatment can be offered to patients diagnosed with PAH and CTEPH, respectively $[1,2]$. The prognosis of $\mathrm{PH}$ varies broadly and depends mostly on etiology of $\mathrm{PH}$, but is also based on hemodynamic and biochemical parameters, which indicate the severity of right ventricular failure, as well as on response to specific treatment. Early recognition of the disease 
and risk stratification seem to be crucial to identifying patients at high risk and optimizing therapeutic management. Thus, biomarkers may specifically indicate the disease and provide information about the disease stage and treatment response in a relatively easily accessible and noninvasive way. The search for novel emerging biomarkers is still ongoing, resulting in a few potential biomarkers mirroring numerous pathophysiological courses. The main focus is on detecting and quantifying abnormal adaptations and remodeling of the right heart in response to chronic pulmonary circulation impairment. However, in the natural course of $\mathrm{PH}$ and right ventricular $\mathrm{HF}$, tissue damage, fibrosis, inflammation, and endothelial dysfunction seem to be also crucial underlying mechanisms, which may be included in noninvasive biomarker assessment (Figure 1). In the present article, we review circulating biomarkers related to different mechanisms underlying the precapillary $\mathrm{PH}$ and describe the potential application for them, highlighting their limitations and necessity for further investigation.

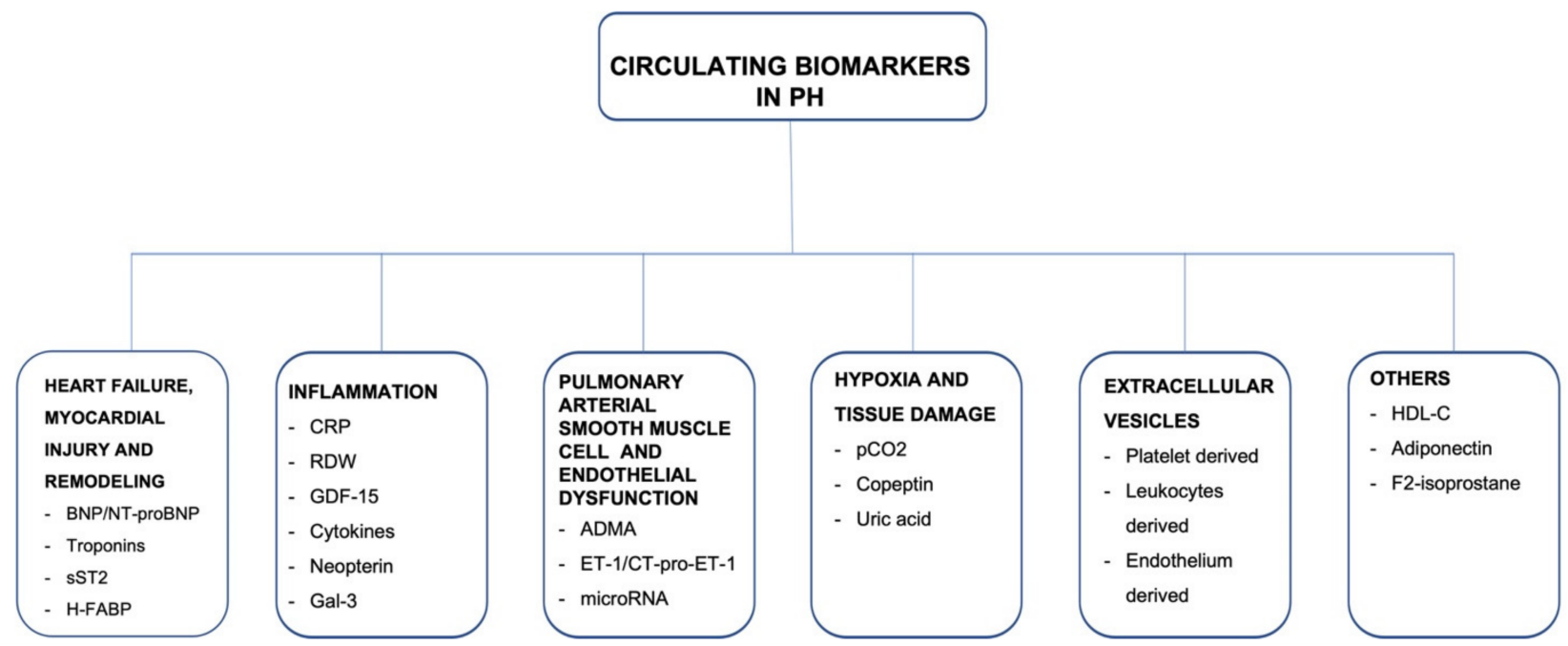

Figure 1. A summary of circulating biomarkers in precapillary pulmonary hypertension.

\section{Biomarkers Related to Heart Failure, Myocardial Injury, and Remodeling}

In PH, elevated PVR and PAP lead to hemodynamic stress, myocardial strain, and stretching of the heart. Consequently, this condition results in the release of the molecular mediators, indicative for numerous cardiovascular diseases with additional prognostic value. Several markers associated with HF, myocardial injury, and myocardial remodeling, such as natriuretic peptides, cardiac troponins, soluble ST2, and heart-type fatty acidbinding protein, have been investigated in a cohort of patients with precapillary $\mathrm{PH}$.

\subsection{Natriuretic Peptides}

Brain-type natriuretic peptide (BNP) is produced as an inactive precursor (proBNP), then converted into the active form N-terminal-pro brain-type natriuretic peptide (NTproBNP) and released from cardiomyocytes. Due to the longer half-life of NT-proBNP compared to BNP, NT-proBNP is preferred in clinical practice as a marker of heart overload and myocardial dysfunction [3,4]. NT-proBNP remains a well-established and widely used biomarker in numerous cardiovascular diseases. It is released in response to ventricular wall stress and myocardial hypoxia or ischemia. NT-proBNP is mostly used in the diagnostic process of patients with acute or chronic HF as well as in predicting prognosis of those patients [5]. In PH patients, serum NT-proBNP levels correlate with right heart dysfunction and provide prognostic information at diagnosis and during follow-up assessment [6-8]. However, due to the high variability of NT-proBNP levels and its possible inadequate correlation with hemodynamic parameters and exercise capacity, it should only be interpreted in the clinical context [6]. At present, NT-proBNP is a crucial element of risk stratification in PAH patients and is addressed in both the risk score developed from the REVEAL registry 
(Registry to Evaluate Early and Long-Term PAH Disease Management) $[9,10]$ and in the risk stratification method proposed by ESC/ERS guidelines [2]. Consistent with REVEAL registry data, a baseline NT-proBNP level of $\leq 340 \mathrm{ng} / \mathrm{L}$ is a strong predictor of improved survival up to 5 years in PAH patients [10]. In slightly different terms, the ESC/ERS guidelines classify NT-proBNP concentrations as low $(<5 \%)$, intermediate $(5-10 \%)$, or high $(>10 \%)$ risk of 1-year mortality, by using specific thresholds of 300 and $1400 \mathrm{ng} / \mathrm{L}$ [2]. A significant decrease in NT-proBNP levels among patients with PAH is associated with the response to targeted medical therapy [11,12]. In CTEPH patients, BNP may not only reflect the degree of RV dysfunction and hemodynamic severity of the disease, but also facilitate to assess the effect of pulmonary endarterectomy (PEA) [13], with estimated BNP baseline cut-off values predictive of worse postoperative survival [14]. Furthermore, both balloon pulmonary angioplasty (BPA) as well as pharmacological treatment result in a decrease of NT-proBNP concentration [15-17]. In patients treated with BPA, a reduction in NT-proBNP concentration is associated with a significant decrease in mean PAP and PVR, thereby indicating the procedural success of BPA [15]. Tables 1 and 2 presents changes in BNP and NT-proBNP concentrations before and after BPA treatment in the hitherto published case series.

Table 1. Changes in BNP levels in CTEPH patients before and after BPA treatment in the hitherto published case series.

\begin{tabular}{cccccc}
\hline Studies & $\begin{array}{c}\text { No. of } \\
\text { Patients (n) }\end{array}$ & $\begin{array}{c}\text { No. of BPA } \\
\text { Sessions (n) }\end{array}$ & $\begin{array}{c}\text { BNP before } \\
\text { BPA (pg/mL) }\end{array}$ & $\begin{array}{c}\text { BNP after BPA } \\
\text { (pg/mL) }\end{array}$ & $p$ \\
\hline Sugimura et al. [18] & 12 & NR & $335 \pm 105$ & $16 \pm 11$ & $\mathrm{~S}$ \\
\hline Kimura et al. [19] & 66 & 446 & $237.7 \pm 475.7$ & $45.2 \pm 47.6$ & $\mathrm{~S}$ \\
\hline Ogo et al. [20] & 80 & 385 & $227 \pm 282$ & $48 \pm 57$ & $\mathrm{~S}$ \\
\hline Yamasaki et al. [21] & 20 & 2.7 per pt & $66.5 \pm 61.3$ & $33.8 \pm 30.0$ & $\mathrm{~S}$ \\
\hline Aoki et al. [22] & 24 & 113 & $112(49-199)$ & $27.5(14.6-58.4)$ & $\mathrm{S}$ \\
\hline Inami et al. [23] & 103 & 350 & $94(42-232)$ & $61(39-150)$ & $\mathrm{S}$
\end{tabular}

Data are presented as mean \pm SD or median and (IQR), S- $p<0.05$; BPA—balloon pulmonary angioplasty; $\mathrm{BNP}$-brain natriuretic peptide.

Table 2. Changes in NT-proBNP levels in CTEPH patients before and after BPA treatment in the hitherto published case series.

\begin{tabular}{|c|c|c|c|c|c|}
\hline Studies & No. of Patients $(n)$ & $\begin{array}{l}\text { No. of BPA } \\
\text { Sessions }(n)\end{array}$ & $\begin{array}{c}\text { NT-proBNP before } \\
\text { BPA (pg/mL) }\end{array}$ & $\begin{array}{c}\text { NT-proBNP after BPA } \\
(\mathrm{pg} / \mathrm{mL})\end{array}$ & $p$ \\
\hline Kurzyna et al. [24] & 31 & 117 & $2571 \pm 2719$ & $634 \pm 697$ & $S$ \\
\hline Olsson et al. [25] & 66 & 446 & $504(233-1676)$ & $242(109-555)$ & $\mathrm{S}$ \\
\hline Araszkiewicz et al. [26] & 15 & 71 & $1554.8 \pm 1541.3$ & $537 \pm 642.6$ & $\mathrm{~S}$ \\
\hline Darocha et al. [27] & 70 & 377 & $1307(510-3294)$ & $206(83-531)$ & $S$ \\
\hline Gerges et al. [28] & 45 & $6(4-10)$ per pt & $579(182-1385)$ & $198(70-429)$ & $S$ \\
\hline
\end{tabular}

Data are presented as mean \pm SD or median and (IQR), S- $p<0.05$; BPA-balloon pulmonary angioplasty; NT-proBNP-N-terminal-pro brain-type natriuretic peptide.

\subsection{Cardiac Troponins}

So far, both cardiac troponin I (cTnI) and T (cTnT) are the principal biomarkers for the detection of myocardial damage and key factors in the diagnosis of acute myocardial infarction [29]. In addition, the development of high-sensitivity assays has made it possible to detect troponin concentrations and their association with morbidity and mortality in many chronic diseases, such as heart failure, coronary artery disease, or chronic kidney disease [30-33]. Although the underlying mechanisms for troponin release in some conditions remain not completely elucidated, in most cases troponins levels correlate with markers of left heart structural abnormalities and other markers related to left HF. In contrast, the 
mechanism of troponin release in PH patients seems to be associated with RV pathology, seemingly caused by demand-perfusion mismatch or microcirculation impairment. These theories are supported by the results from several research studies, in which significant correlations between troponins concentration and hemodynamic parameters, including mean PAP (mPAP), mixed venous oxygen saturation (mvSatO2), and RV ejection fraction, were identified $[34,35]$. Moreover, both $\mathrm{cTnT}$ and $\mathrm{cTnI}$ concentrations were associated with worse outcomes in mixed cohorts of PH patients [34,36]. Thereby, ESC guidelines indicate that for comprehensive prognostic assessment and risk stratification, troponin levels should be measured at the diagnosis of $\mathrm{PAH}$, then at least once a year or whenever the patient presents with clinical worsening [2]. In CTEPH patients undergoing interventional treatment with BPA, high-sensitivity cTnT concentration decreases stepwise under therapy, signifying a reduction of ongoing myocardial damage due to decreased right ventricular afterload after BPA therapy [37]. Thus, also in the CTEPH patient population, troponins can be a useful marker to monitor the progress of treatment.

\subsection{Soluble ST2}

Soluble ST2 (sST2) protein is another promising biomarker in PH patients. Protein ST2 belongs to the Toll interleukin 1 receptor superfamily and exists in two isoforms: transmembrane ST2 ligand (ST2L) and soluble ST2 (sST2), which circulates in the blood. The transmembrane form is expressed mainly on inflammatory cells and takes part in strengthening of the immune response of Th2 lymphocytes. However, it is also exposed in cardiomyocytes and endothelium [38]. The ligand for ST2 is interleukin 33 (IL-33), whose expression increases due to mechanical overload and ischemia of cardiomyocytes [38]. The paracrine IL-33/ST2L system plays a protective role, counteracting fibrosis and myocardial hypertrophy. The sST2 protein, which prevents IL-33 binding to the ST2L, is responsible for interrupting this protective action. The balance between both isoforms of ST2 protein ensures the correct biological effect [38,39]. The increase of sST2 concentration in plasma is associated with cardiac remodeling and hemodynamic stress [38-40]. Besides natriuretic peptide family and cardiac troponins, sST2 protein may be an additional biomarker for adverse outcomes in cohorts of patients with acute and chronic heart failure [41-43]. The sST2 level above $35 \mathrm{ng} / \mathrm{mL}$ in patients with HF is associated with higher risk of adverse events, defined as hospitalization or death in one year, in comparison to subjects with sST2 level below this value [44-46]. At present, there is increasing evidence of the use of the sST2 protein for risk stratification in patients with RV failure due to PH. In different types of PH, higher sST2 levels are linked to the remodeling of the RV [47]. In a study involving 100 patients diagnosed with PAH or CTEPH, significant correlations between sST2 and cardiac index $(\mathrm{CI})$, mean right atrial pressure (mRAP), PVR, mvSatO2, NT-proBNP concentration, and 6 min walking distance (6MWD) were noticed [48]. These observations are consistent with those from other studies conducted in smaller populations of patients with precapillary PH $[49,50]$. Moreover, sST2 has been assessed as a marker of therapy response in $57 \mathrm{CTEPH}$ patients, treated with BPA. In detail, the median SST2 concentration decreased to the range of control group after interventional treatment, but it was not related to the individual grade of response to BPA therapy [51]. In another study, sST2 concentration changed significantly in $37 \mathrm{CTEPH}$ patients treated with BPA in the immediate postprocedural period. Interestingly, in patients who experienced complications in the postprocedural period, the baseline SST2 levels were significantly higher in comparison to those without complications. Thereby, SST2 could be beneficial for preoperative risk assessment in these patients. Furthermore, sST2 concentration significantly increased early after BPA procedure, irrespective of complications. In contrast, no analogous changes in NT-proBNP levels were noticed, which may be suggestive of an additional noncardiac source of sST2 in CTEPH patients. Therefore, in PH, sST2 as a complex biomarker may reflect not only the heart condition but also pulmonary vascular system and lung tissue [52]. Table 3 summarizes the main differences between sST2 and NT-proBNP in management of $\mathrm{PH}$. 
Table 3. Main differences between NT-proBNP and soluble ST2 as biomarkers in PH.

\begin{tabular}{|c|c|c|}
\hline Feature & Soluble ST2 Protein & BNP/NT-proBNP \\
\hline Origin & $\begin{array}{l}\text { The Toll-like receptor superfamily } \\
\text { binding IL-1; Il33-ST2 pathway }\end{array}$ & Oligopeptide nuerohormones \\
\hline Source of secretion & $\begin{array}{l}\text { Cardiomyocytes, endothelial cells, } \\
\text { inflammatory cells }\end{array}$ & Cardiomyocytes \\
\hline Form & $\begin{array}{l}\text { Two isoforms: transmembrane } \\
\text { ST2-ligand (ST2L) and soluble ST2 (sST2) }\end{array}$ & N-terminal fragment of prohormone \\
\hline Physiological function & $\begin{array}{l}\text { Cardioprotective role, enhancement of } \\
\text { Th2-dependent immune response }\end{array}$ & $\begin{array}{l}\text { Cardiovascular homeostasis, } \\
\text { vasodilatation }\end{array}$ \\
\hline Pathophysiological basis & Cardiac remodeling and fibrosis & Hemodynamic condition \\
\hline Secretion factor & $\begin{array}{l}\text { Hemodynamic stress and myocardial } \\
\text { remodeling; inflammation }\end{array}$ & Pressure and volume overload \\
\hline Age- and renal function-dependence & $\mathrm{NO}$ & YES \\
\hline Role in diagnosis of $\mathrm{PH}$ & $\mathrm{NO}$ & YES \\
\hline Role in prognosis of $\mathrm{PH}$ & YES & YES \\
\hline Correlation with disease severity & YES & YES \\
\hline Correlation with treatment effect & YES & YES \\
\hline
\end{tabular}

$\mathrm{BNP}$-brain natriuretic peptide; NT-proBNP-N-terminal-pro brain-type natriuretic peptide.

\subsection{Heart-Type Fatty Acid-Binding Protein}

Heart-type fatty acid-binding protein (H-FABP) is a low-molecular-weight protein, which is expressed in the cytosol of cardiomyocytes. H-FABP appears to be a marker of injury of cardiomyocytes and is also considered as additional biomarker for early diagnosis of acute coronary syndrome [53]. Of note, Puls et al. described H-FABP as a suitable marker for risk assessment in patients with acute pulmonary embolism [54]. However, there are only limited data about the application of H-FABP in PH patients. Lankeit et al. examined the role of H-FABP in risk stratification in CTEPH patients. The results of the study revealed $\mathrm{H}-\mathrm{FABP}$ as an independent marker of adverse outcomes, defined as persistent $\mathrm{PH}$ after PEA, CTEPH-related death, or lung transplantation [55]. In contrast, Mirna et al. identified $\mathrm{H}-\mathrm{FABP}$ as an indicator of postcapillary, but not precapillary PH [56]. Although these initial reports appear promising, further studies enrolling a larger population are needed in order to evaluate existing discrepancies.

\section{Markers of Inflammation}

There is increasing evidence that inflammation processes have great significance in the pathophysiology of $\mathrm{PH}$, being involved in pulmonary arterial remodeling. However, the inflammatory component could also mirror organs distress caused by a certain degree of ischemia and elevated sympathetic drive as a consequence of limited cardiac output. A variety of both anti- and proinflammatory molecules have been investigated as potential biomarkers in cohorts of $\mathrm{PH}$ patients.

\subsection{C-Reactive Protein}

C-reactive protein (CRP), a widely used marker of inflammation, is broadly established as a predictor of numerous cardiovascular diseases, including different types of $\mathrm{PH}$. In PAH, significant correlations between CRP and RAP, 6MWD as well as NYHA class were revealed [57]. Scognamiglio et al. observed that in patients with congenital heart disease-associated PAH (CHD-PAH), CRP concentration was commonly increased and the CRP elevation above $10 \mathrm{mg} / \mathrm{mL}$ was associated with around four times greater risk of death [58]. Wynants et al. examined CRP effects on pulmonary vascular cells in CTEPH patients. They revealed that CRP could play a role in chronic obstruction of pulmonary 
arteries by stimulating endothelial dysfunction, vascular remodeling, and in situ thrombosis [59]. In CTEPH patients, plasma CRP concentrations were related to tissue factor (TF) antigen, suggesting the connection between thrombosis and inflammatory processes in the pathogenesis of CTEPH [60]. Moreover, Quarck et al. observed that CRP levels were elevated among CTEPH patients and significantly decreased 12 months after PEA [57]. However, due to the reported elevated CRP levels in many clinical conditions, including various cardiovascular diseases, its potential use in the diagnosis and monitoring of $\mathrm{PH}$ patients remains limited.

\subsection{Red Blood Cell Distribution Width}

Red blood cell distribution width (RDW) is a laboratory biomarker of heterogeneity, regularly measured in standard blood analyses. Elevated RDW levels are the sign of anisocytosis, which is linked with underlying inflammatory processes [61]. So far it is known that RDW may be a predictor of survival in various cardiovascular diseases, such as coronary artery disease [62], chronic heart failure [63], or acute pulmonary embolism [64]. Moreover, RDW is a prognostic marker of $\mathrm{PH}$ of different etiologies, and an association with mortality in a cohort of $\mathrm{PH}$ patients was noticed $[65,66]$. In study involving 77 inoperable CTEPH and PAH patients, the decrease in RDW level after initiation or escalation of specific treatment was linked with good treatment response and improved prognosis [67]. Similar results were previously obtained by Wang et al. in 56 CTEPH patients [68]. However, there is a need for prospective studies to better assess the prognostic value of RDW in cohorts of patients with precapillary $\mathrm{PH}$.

\subsection{Growth Differentiation Factor-15}

Growth differentiation factor-15 (GDF-15) is a member of the TGF $\beta$ superfamily. GDF15 is exposed in various types of cells in response to tissue damage, ischemia, or shear stress $[69,70]$. So far, GDF-15 has been indicated as a nonspecific marker of systemic stress in several cardiovascular diseases [71]. In PH, GDF-15 is present in the plexiform lesions in the pulmonary vascular bed and may thus affect both apoptosis and proliferation of endothelial cells [69]. Nickel et al. revealed that in 22 patients with iPAH, GDF-15 levels were associated with hemodynamic parameters such as RAP and pulmonary capillary wedge pressure (PCWP), as well as with biochemical parameters, such as NT-proBNP concentration. However, there were no significant changes in median GDF-15 levels measured prior to beginning of specific therapy and at three- or six-month follow-up [72]. Furthermore, in a study by Meadows et al. in patients with scleroderma and associated PAH, GDF-15 was a marker of reduced survival and correlated with NT-proBNP levels and right ventricular systolic pressure assessed by transthoracic echocardiography [73]. The observations mentioned above brightly propose that GDF-15 could be a prognostic factor in PAH. GDF-15 was also assessed as a marker in therapy response in CTEPH patients treated with BPA. Kriechbaum et al. revealed no significant changes before and after BPA treatment, but there was a correlation between delta change in GDF-15 levels and the change in CI and RAP. In addition, a low concentration of GDF-15 measured at baseline indicated responders to the BPA therapy at the follow-up [51].

\subsection{Cytokines}

Various cytokines are considered crucial inflammatory mediators in numerous conditions, including PH. In a study conducted by Soon et al., serum levels of several interleukins (IL), such as IL-1, IL-2, IL-4, IL-6, IL-8, Il-10, and IL-12p70, and tumor necrosis factor- $\alpha$ $(\mathrm{TNF} \alpha)$ were higher in patients with $\mathrm{PAH}$ in comparison to a group of healthy controls. From the ILs mentioned above, IL-6, IL-8, IL-10, and IL-12p70 were prognostic factors of poor survival in iPAH and familial PAH [74]. These data are consistent with results obtained by Selimovic et al., which revealed significantly higher levels of IL-6, transforming growth factor $\beta 1$ (TGF $\beta 1$ ), platelet-derived growth factor (PDGF), and vascular endothelial growth factor (VEGF) in PAH patients compared to controls. Moreover, in this study, a sig- 
nificant association between IL-6 and mortality was observed [75]. Similar observations were previously revealed by Langer et al. in a cohort of CTEPH patients [76]. Elevated levels of IL-6, IL-8, and TNF $\alpha$ were observed in CTEPH patients before PEA. Hence, both IL-6 and Il-8 presented a noticeable peak immediately after PEA, whereas TNF $\alpha$ levels significantly decreased within $24 \mathrm{~h}$ after the procedure [76]. What is more, in a study conducted by Zabini et al., significant correlations of IL-6 and hemodynamic parameters and exercise capacity were observed [77]. As mentioned above, numerous cytokines have been investigated as potential biomarkers in $\mathrm{PH}$ patients, but their applicability remains still in the research phase.

\subsection{Neopterin}

Neopterin (NP), belonging to the class of pteridines, is a marker of cellular immune response. NP is predominantly released by dendritic cells and macrophages after stimulation with interferon $\gamma($ IFN $\gamma$ ) via guanosine triphosphate (GTP) cyclohydrolase I [78]. The crucial pathophysiological role of NP is presumably the interaction with reactive oxygen or nitrogen intermediates, in that way stimulating oxidative stress [79]. Elevated levels of NP have been observed in various clinical conditions, including cardiovascular diseases, such as heart failure and coronary artery disease [80,81]. Moreover, in the above-mentioned conditions, NP has been documented as a biomarker associated with death and adverse-event prognosis. NP could participate in the progression of various types of $\mathrm{PH}$ by intensifying effects of reactive oxygen species. However, there are only limited data about NP used as a biomarker in patients with PH. In the study including $50 \mathrm{PAH}$ and inoperable CTEPH patients, NP levels were significantly higher in comparison to healthy controls. Moreover, positive correlations of NP with NT-proBNP, right atrium area, and negative correlations with 6MWD and peak-VO2 assessed in cardiopulmonary exercise test (CPX) were reported. Additionally, elevated NP levels were associated with poor clinical outcomes in a cohort of $\mathrm{PH}$ patients [82].

\subsection{Galectin 3}

Galectin-3 (Gal-3) is a beta-galactoside-binding lectin, expressed in the inflammatory cells (macrophages, neutrophils, eosinophils, and mast cells) and endothelial cells in response to tissue damage. Gal-3 is considered to be mediator of inflammatory processes and fibrosis, and its activity results in increased adverse cardiac remodeling [83,84]. Healthy cardiomyocytes are characterized by low Gal-3 expression, whereas in patients diagnosed with heart diseases, Gal-3 levels increase with disease severity [85]. In recent years, many studies have aimed to demonstrate the role of Gal-3 in diagnosis and prognosis of left-sided HF. Multiple measurements of Gal-3 levels in two large cohorts of patients with chronic and acute HF provided important information on the prognostic value of Gal-3 in identifying high risk of morbidity and mortality [86-88]. However, Gal-3 may be suitable also for monitoring right ventricular remodeling [89]. There are only limited data about the role of Gal-3 measurements among PH patients, focusing mainly on patients with PAH and consisting of small cohorts. Calvier et al. demonstrated high levels of Gal-3 in PAH patients and revealed correlations between Gal-3 and functional parameters [90]. Mazurek et al. observed that elevated levels of Gal-3 were associated with mortality in PH patients, but the study involved both PAH and PH due to left-sided HF patients [91]. In the study conducted by Geenen et al., including 164 patients with $\mathrm{PAH}, \mathrm{CTEPH}$, or $\mathrm{PH}$ caused by lung disease, there were no significant differences in the Gal-3 levels between subgroups [92]. However, higher levels of Gal-3 were associated with adverse outcomes, defined as death, hospitalization, or lung transplantation. In another study, Gal-3 was evaluated in relation to disease severity and treatment response in patients with CTEPH treated with BPA. In the context of risk assessment and evaluation of therapy response, no diagnostic benefits were revealed [51]. 


\section{Biomarkers Related to Pulmonary Arterial Smooth Muscle Cell and Endothelial Dysfunction}

Although the pathogenesis of PAH is fundamentally different from that of CTEPH, it has been shown that changes in pulmonary arterial microcirculation can be similar in both types, including excessive pulmonary arterial smooth muscle cell (PASMC) proliferation and endothelial dysfunction. There are several biomarkers linked to endothelial cells and PASMC studied in the PH patient population.

\subsection{Asymmetric Dimethylarginine}

Asymmetric dimethylarginine (ADMA), produced by endothelial cells, is a competitive nitric oxide synthase inhibitor [93]. As we know from several reports, ADMA levels are higher and are associated with adverse outcomes in patients with different types of $\mathrm{PH}$, including idiopathic PAH and CTEPH, but also with other diseases, including acute myocardial infarction [94]. In study conducted by Kilestein et al., ADMA correlated with CI, RAP, and mvSatO2 and was an independent predictive factor of mortality in PAH [95]. Similar correlations were achieved by Skoro-Sajer et al. in a cohort of CTEPH patients [96]. Furthermore, Sanli et al. revealed higher ADMA concentrations in pediatric patients diagnosed with congenital heart disease [97].

\subsection{Endothelin-I and COOH-Terminal Pro Endothelin 1}

Endothelin-I (ET-I), involved in cardiovascular hemostasis and respiratory development, promotes PASMC proliferation and migration and is considered an effective vasoconstrictor [98-100]. In patients with different types of PH, high levels of ET-1 and significant correlations of ET-1 with hemodynamic parameters are observed. At present, in the treatment of PAH, endothelin receptor antagonists are well established and commonly used with favorable effects [98,101]. In CTEPH, preoperative high ET-1 levels correlate positively with clinical severity of the disease, being potential predictors of hemodynamic effects after PEA [102]. These observations were also confirmed by Reesink et al., whose study showed ET-1 levels in CTEPH patients were useful for identifying patients at risk for residual or persistent PH after surgical treatment [103]. However, there are some specific obstacles that make ET-1 not an attractive biomarker. These obstacles can be overcome by $\mathrm{COOH}$-terminal pro endothelin 1 (CT-proET-1). Firstly, there is no correlation between ET-1 levels in lung and plasma, which may be explained by its paracrine functions [104]. Secondly, direct measurement of ET-1 levels can be affected by cross-reactivity. On the contrary, CT-pro-ET-1 is present in plasma and remains stable at room temperature for a few hours [105]. In the study performed by Marques et al., including 28 patients with $\mathrm{PAH}$, plasma CT-pro-ET-1 levels were associated with functional parameters and were predictors of hospitalization, death, or lung transplantation within 12-month follow-up [106].

\subsection{MicroRNAs as Biomarkers in PAH}

MicroRNAs(miRNAs) are small, endogenously expressed noncoding RNAs, circulating in the blood. MiRNAs regulate gene expression at the posttranscriptional level by degrading or stopping target RNAs [107]. MiRNAs measurements may play a role as biomarkers for several pathologies, including HF or acute myocardial infarction $[108,109]$. Finally, miRNAs are engaged in the progression of $\mathrm{iPAH}$, including plexiform lesion creation, endothelial dysfunction, smooth muscle cell proliferation, and both activation and proliferation of fibroblasts [110]. There is evidence for miRNAs as markers of PAH progression. Rothman et al. revealed reduced levels of miR-140-5p in PAH patients in comparison to control group. Further, inhibition of miR-140-5p promotes PASMC proliferation and migration in vitro, which may be relevant in the progression of the disease [111]. Sarrion et al. assessed circulating miRNAs in 12 patients with idiopathic PAH. As a result, they found significant changes in 61 miRNAs. Additionally, correlations between the expression of miR23a and hemodynamic parameters, such as mean PAP, CI, and PVR, were observed. Additionally, the expression profile of circulating messenger RNA (mRNAs) was stud- 
ied, and results revealed that miR23a controlled $17 \%$ of the significantly changed mRNA, including PGC1 $\alpha$, which is related to the progression of iPAH [112].

\section{Markers of Hypoxia and Tissue Damage}

The natural course of PH leads to low cardiac output and respiratory mismatch, which in sequence turn to peripheral hypoperfusion. Thereby, biomarkers mirroring peripheral damage and hypoperfusion, such as partial pressure of carbon dioxide (pCO2) and copeptin, could be tools in monitoring disease progression and ascertaining prognosis.

\section{1. $p \mathrm{CO} 2$}

As is well known, pCO2 levels are constantly decreased in patients with different types of $\mathrm{PH}$. In accordance to a retrospective study conducted by Hoeper et al., decreased pCO2 levels in $\mathrm{PAH}$ patients were associated with poor prognosis, whereas decreased $\mathrm{pO} 2$ levels had no prognostic significance. Interestingly, in the same study, the improvement of pCO2 after 3 months of PAH targeted therapy was noted, and that was associated with higher survival rate [113]. However, a recent study conducted by Valentin et al. revealed that in PAH patients, $a \geq 3 \%$ decrease in arterial oxyhemoglobin saturation $(\mathrm{SaO} 2)$, noticed after 3 months of treatment with PAH-specific drugs, was associated with worse outcomes [114].

End-tidal partial pressure of $\mathrm{CO} 2\left(\mathrm{P}_{\mathrm{ET}} \mathrm{CO} 2\right)$ is a measurement made at the airway during $\mathrm{CPX}$. In normal individuals, $\mathrm{P}_{\mathrm{ET}} \mathrm{CO} 2$ increases from rest to the anaerobic threshold (AT), then stabilizes during the isocapnic buffering period and finally decreases later during exercise [115]. In both $\mathrm{PAH}$ and $\mathrm{CTEPH}, \mathrm{P}_{\mathrm{ET}} \mathrm{CO} 2$ is frequently low at rest and declines further during early exercise. In detail, $\mathrm{P}_{\mathrm{ET}} \mathrm{CO} 2$ at $\mathrm{AT}$ less than $30 \mathrm{mmHg}$ may be suggestive for pulmonary vascular disease in patients with unexplained dyspnea, whereas values greater than $38 \mathrm{mmHg}$ make $\mathrm{PH}$ diagnosis unlikely. Low values of $\mathrm{P}_{\mathrm{ET}} \mathrm{CO} 2$ are associated with altered chemosensitivity, ventilatory inefficiency, and high dead space ventilation, due to reduced perfusion of highly ventilated alveoli. The magnitude of $\mathrm{P}_{\mathrm{ET}} \mathrm{CO} 2$ reduction inversely correlated with the degree of mPAP elevation in a cohort of $\mathrm{PH}$ patients [116].

\subsection{Uric Acid}

Uric acid (UA) is the end product of purine metabolism and a marker of impaired oxidative metabolism. UA can be produced due to various conditions, such as cardiac overproduction, renal impairment, or use of diuretics in right-sided HF. Serum UA levels have been presented to be elevated in patients with both left- and right-sided HF [117]. Thus, the use of UA as a marker in PH remains debatable. Nagaya et al. revealed significantly increased serum levels of UA in PH patients. Further, serum UA levels were independently related to mortality [118]. In another study by Voelkel et al., patients with severe PH had higher levels of UA and UA levels were positively correlated with RAP [119]. Wang et al. assessed UA levels in a cohort of 50 patients diagnosed with PAH related to connective tissue disease (CTD-PAH). They observed that patients with increased levels of UA at baseline had a lower survival rate in comparison to those with normouricemia. It is suggestive for UA levels as a prognostic factor in CTD-PAH patients [120]. Interestingly, in pediatric PAH patients, treatment with prostacyclin was able to reduce UA levels [121]. However, it remains unclear whether treatment of increased UA concentrations has an influence on prognosis. Finally, the main limitation of UA as a marker is lack of specificity for $\mathrm{PH}$.

\subsection{Copeptin}

Copeptin, the C-terminal fragment of the vasopressin's precursor, is an emerging surrogate target for assessment of vasopressin levels. Copeptin has arisen as a valuable tool in monitoring cardiovascular pathologies. As known from previous reports, copeptin can deliver additional information to troponin in the initial assessment process of patients with chest pain [122-124]. In patients diagnosed with chronic HF, copeptin increases the diagnostic value of NT-proBNP as a predictor of all-cause mortality [122,125]. In PAH patients, copeptin significantly correlates with 6MWD and NYHA class as well as with kidney 
function [126-128]. Moreover, in a study performed by Nickel et al., elevated copeptin concentration was related to a higher risk of death and was an independent predictive factor of adverse outcomes in PAH patients. Noteworthy, copeptin levels were independent of hemodynamic parameters, but correlated well with NT-proBNP concentration, both at baseline and after initiation of treatment targeting pulmonary arterioles. Consequently, copeptin might mirror neurohumoral activation due to altered function of the RV. Thus, elevated copeptin levels could add significant prognostic information that is not captured by RHC or NT-proBNP concentration assessed alone [129]. Summarizing, copeptin could be an additional biomarker in multimarker testing strategies for better risk stratification in PH patients.

\section{Extracellular Vesicles}

There is increasing evidence suggesting an active role for extracellular vesicles (EVs) in the pathophysiology of PH. Extracellular vesicles have different origins, such as endothelial cells, leukocytes, and platelets $[130,131]$. The concentration of EVs increases differently and specifically in various pathological conditions, including cardiovascular diseases [132]. In detail, in studies conducted by Amabile et al., circulating EVs of leukocyte (CD11b+), platelet $(\mathrm{CD} 31+\mathrm{CD} 61+)$, as well as endothelial $(\mathrm{CD} 62 \mathrm{e}+)$ origin, measured by flow cytometry, were higher in patients with $\mathrm{PH}$ in comparison to controls. In addition, endothelial EVs levels correlated with the hemodynamic severity of PAH and were associated with adverse clinical events $[131,133]$. Moreover, PAH patients had higher endothelial EV concentrations compared to patients with chronic pulmonary disease-related PH [131]. These observations indicate the potential role of EVs in the disease onset and progression of PAH. In detail, both leukocyte and platelet EVs promote destruction of the pulmonary endothelium and remodeling of the PASMC. On the other hand, Diehl et al. reported higher levels of endothelial EVs bearing E-selectin in thromboembolic $\mathrm{PH}$ in comparison to non-thromboembolic $\mathrm{PH}$ patients [130]. Gasecka et al. investigated EVs levels in $42 \mathrm{PAH}$ patients treated with prostacyclin analogues. Patients during treatment with prostacyclin analogues had similar concentrations of EVs from platelets, but lower concentrations of EVs from leukocytes and activated platelets in comparison to patients treated with phosphodiesterase type 5 inhibitor and/or endothelin receptors antagonists. Moreover, the authors noticed a trend toward a lower concentration of EVs from endothelial cells in patients treated with prostacyclin analogues [134]. These results may suggest that the decrease of EVs levels might be one of the mechanisms underlying the favorable effects of prostacyclin analogues in PAH patients.

\section{Other Biomarkers}

\subsection{High-Density Lipoprotein Cholesterol}

High-density lipoprotein cholesterol (HDL-C) is a well-known biomarker of various cardiovascular diseases. In two studies among PAH patients, decreased levels of HDL-C were measured. Moreover, levels of HDL-C were strongly associated with survival in patients with $\mathrm{PAH}[135,136]$. In a retrospective study involving 90 patients suffering from $\mathrm{CTEPH}$, high levels of HDL-C significantly correlated with a decrease in right ventricular dilatation and a considerable reduction in PVR after surgical treatment [137].

\subsection{Adiponectin}

Adiponectin (APN) is an adipokine, completely produced and secreted in the adipose tissue. However, in addition to adipocytes, APN is exposed also in various other cell types, such as cardiomyocytes and endothelial cells $[138,139]$. In PH, APN is considered to exert a cardioprotective effect, by reducing inflammatory processes and inhibiting vascular smooth muscle cells proliferation [119]. In a study of $30 \mathrm{CTEPH}$ patients, APN levels were elevated and positively correlated with hemodynamic parameters, such as PVR, and with BNP concentration. Moreover, levels of APN decreased significantly after improvement of RV function due to BPA or PEA. Thus, changes in APN levels in association with hemodynamic 
severity and clinical outcome are suggestive for the role of APN as a prognostic biomarker in PH [140]. However, given that the exact role of adiponectin in PH has not yet been fully understood, further studies are needed to better evaluate this biomarker.

\section{3. $F(2)$-Isoprostane}

$\mathrm{F}(2)$-isoprostane is a marker of lipid peroxidation, measured both in urine and in plasma samples. It is regarded as an oxidative stress marker; however, its source has not been identified yet. Data assessing F(2)-isoprostane among PH patients are limited. Cracowski et al. prospectively assessed urine $\mathrm{F}(2)$-isoprostane levels in 110 PAH patients. They revealed that $\mathrm{F}(2)$-isoprostane was an independent predictive factor of mortality in this cohort. Moreover, they also observed that $\mathrm{F}(2)$-isoprostane measurement in children with family history of PAH can help in early detection of the disease [123,141]. In another study, Zhang et al. determined $\mathrm{F}(2)$-isoprostane plasma levels in 80 patients diagnosed with iPAH at the time of their first RHC and monitored them for $30 \pm 12$ months. F(2)-isoprostane were elevated in the study population and significant correlations with WHO functional class, 6MWD, mvSatO2, mRAP, and BNP were noticed. Moreover, F(2)-isoprostane concentration increased further in nonsurviving patients despite similar targeted treatment being administered in both survivors and nonsurvivors. Histological studies presented that the expression of $\mathrm{F}(2)$-isoprostane was upregulated in remodeled pulmonary vessels in autopsy lung samples [142].

\section{Conclusions}

The present article reviews several promising biomarkers that have been identified and assessed in $\mathrm{PH}$ patients over the past few years. Although a wide range of biomarkers have been explored, none of them are specific enough to be used alone in the diagnostic process and prognosis assessment. Moreover, the majority of biomarkers mentioned in this review have been evaluated in retrospective studies with a small number of patients and/or controls, divergent studied population, and with potential selection bias. Therefore, part of the available data should be taken with caution. Larger, prospective clinical trials are needed to validate potential biomarkers for both diagnosis and prognosis. Furthermore, given the complexity of the disease, it remains unlikely that a single biomarker can be used successfully in patients with precapillary PH. Multimarker strategies for risk assessment, as applied in patients with left HF, should be investigated and validated in $\mathrm{PH}$.

Author Contributions: Investigation: M.B.; writing—original draft preparation: M.B.; writingreview and editing-A.G.; supervision: M.F., S.D., P.K., A.P., M.P., A.T. and M.K. All authors have read and agreed to the published version of the manuscript.

Funding: This study was supported by funds from the statuatory activity of the Centre of Postgraduate Medical Education in Warsaw, Poland (grant number 501-1-054-25-21).

Institutional Review Board Statement: Not applicable.

Informed Consent Statement: Not applicable.

Data Availability Statement: All of the cited data in this review has come from professional medical literature cited in the Reference section according to order of appearance. Data that describe the experience of this review's authors have also been properly cited, as they come from our peerreviewed published articles and book chapters.

Conflicts of Interest: The authors declare no conflict of interest. 


\section{References}

1. Galie, N.; McLaughlin, V.V.; Rubin, L.J.; Simonneau, G. An overview of the 6th World Symposium on Pulmonary Hypertension. Eur. Respir. J. 2019, 53, 1802148. [CrossRef] [PubMed]

2. Galie, N.; Humbert, M.; Vachiery, J.L.; Gibbs, S.; Lang, I.; Torbicki, A.; Simonneau, G.; Peacock, A.; Noordegraaf, A.V.; Beghetti, M.; et al. 2015 ESC/ERS Guidelines for the diagnosis and treatment of pulmonary hypertension: The Joint Task Force for the Diagnosis and Treatment of Pulmonary Hypertension of the European Society of Cardiology (ESC) and the European Respiratory Society (ERS): Endorsed by: Association for European Paediatric and Congenital Cardiology (AEPC), International Society for Heart and Lung Transplantation (ISHLT). Eur. Respir. J. 2015, 46, 903-975. [CrossRef]

3. Leuchte, H.H.; El Nounou, M.; Tuerpe, J.C.; Hartmann, B.; Baumgartner, R.A.; Vogeser, M.; Muehling, O.; Behr, J. N-terminal pro-brain natriuretic peptide and renal insufficiency as predictors of mortality in pulmonary hypertension. Chest 2007, 131, 402-409. [CrossRef] [PubMed]

4. Williams, M.H.; Handler, C.E.; Akram, R.; Smith, C.J.; Das, C.; Smee, J.; Nair, D.; Denton, C.P.; Black, C.M.; Coghlan, J.G. Role of $\mathrm{N}$-terminal brain natriuretic peptide (N-TproBNP) in scleroderma-associated pulmonary arterial hypertension. Eur. Heart J. 2006, 27, 1485-1494. [CrossRef] [PubMed]

5. Ponikowski, P.; Voors, A.A.; Anker, S.D.; Bueno, H.; Cleland, J.G.; Coats, A.J.; Falk, V.; Gonzalez-Juanatey, J.R.; Harjola, V.P.; Jankowska, E.A.; et al. 2016 ESC Guidelines for the diagnosis and treatment of acute and chronic heart failure: The Task Force for the diagnosis and treatment of acute and chronic heart failure of the European Society of Cardiology (ESC). Developed with the special contribution of the Heart Failure Association (HFA) of the ESC. Eur. J. Heart Fail. 2016, 18, 891-975. [CrossRef] [PubMed]

6. Berghaus, T.M.; Kutsch, J.; Faul, C.; von Scheidt, W.; Schwaiblmair, M. The association of N-terminal pro-brain-type natriuretic peptide with hemodynamics and functional capacity in therapy-naive precapillary pulmonary hypertension: Results from a cohort study. BMC Pulm. Med. 2017, 17, 167. [CrossRef]

7. Souza, R.; Jardim, C.; Fernandes, C.J.C.; Lapa, M.S.; Rabelo, R.; Humbert, M. NT-proBNP as a tool to stratify disease severity in pulmonary arterial hypertension. Respir. Med. 2007, 101, 69-75. [CrossRef]

8. Fijalkowska, A.; Kurzyna, M.; Torbicki, A.; Szewczyk, G.; Florczyk, M.; Pruszczyk, P.; Szturmowicz, M. Serum N-terminal brain natriuretic peptide as a prognostic parameter in patients with pulmonary hypertension. Chest 2006, 129, 1313-1321. [CrossRef]

9. Benza, R.L.; Gomberg-Maitland, M.; Elliott, C.G.; Farber, H.W.; Foreman, A.J.; Frost, A.E.; McGoon, M.D.; Pasta, D.J.; Selej, M.; Burger, C.D.; et al. Predicting Survival in Patients With Pulmonary Arterial Hypertension: The REVEAL Risk Score Calculator 2.0 and Comparison With ESC/ERS-Based Risk Assessment Strategies. Chest 2019, 156, 323-337. [CrossRef] [PubMed]

10. Benza, R.L.; Miller, D.P.; Barst, R.J.; Badesch, D.B.; Frost, A.E.; McGoon, M.D. An evaluation of long-term survival from time of diagnosis in pulmonary arterial hypertension from the REVEAL Registry. Chest 2012, 142, 448-456. [CrossRef]

11. Chin, K.M.; Rubin, L.J.; Channick, R.; Di Scala, L.; Gaine, S.; Galie, N.; Ghofrani, H.A.; Hoeper, M.M.; Lang, I.M.; McLaughlin, V.V.; et al. Association of N-Terminal Pro Brain Natriuretic Peptide and Long-Term Outcome in Patients With Pulmonary Arterial Hypertension. Circulation 2019, 139, 2440-2450. [CrossRef] [PubMed]

12. Galie, N.; Jansa, P.; Pulido, T.; Channick, R.N.; Delcroix, M.; Ghofrani, H.A.; Le Brun, F.O.; Mehta, S.; Perchenet, L.; Rubin, L.J.; et al. SERAPHIN haemodynamic substudy: The effect of the dual endothelin receptor antagonist macitentan on haemodynamic parameters and NT-proBNP levels and their association with disease progression in patients with pulmonary arterial hypertension. Eur. Heart J. 2017, 38, 1147-1155. [CrossRef]

13. Nagaya, N.; Ando, M.; Oya, H.; Ohkita, Y.; Kyotani, S.; Sakamaki, F.; Nakanishi, N. Plasma brain natriuretic peptide as a noninvasive marker for efficacy of pulmonary thromboendarterectomy. Ann. Thorac. Surg. 2002, 74, 180-184. [CrossRef]

14. Surie, S.; Reesink, H.J.; van der Plas, M.N.; Hardziyenka, M.; Kloek, J.J.; Zwinderman, A.H.; Bresser, P. Plasma brain natriuretic peptide as a biomarker for haemodynamic outcome and mortality following pulmonary endarterectomy for chronic thromboembolic pulmonary hypertension. Interact. Cardiovasc. Thorac. Surg. 2012, 15, 973-978. [CrossRef] [PubMed]

15. Kriechbaum, S.D.; Wiedenroth, C.B.; Wolter, J.S.; Hutz, R.; Haas, M.; Breithecker, A.; Roller, F.C.; Keller, T.; Guth, S.; Rolf, A.; et al. N-terminal pro-B-type natriuretic peptide for monitoring after balloon pulmonary angioplasty for chronic thromboembolic pulmonary hypertension. J. Heart Lung Transplant. 2018, 37, 639-646. [CrossRef] [PubMed]

16. Sadushi-Kolici, R.; Jansa, P.; Kopec, G.; Torbicki, A.; Skoro-Sajer, N.; Campean, I.A.; Halank, M.; Simkova, I.; Karlocai, K.; Steringer-Mascherbauer, R.; et al. Subcutaneous treprostinil for the treatment of severe non-operable chronic thromboembolic pulmonary hypertension (CTREPH): A double-blind, phase 3, randomised controlled trial. Lancet Respir. Med. 2019, 7, 239-248. [CrossRef]

17. Ghofrani, H.A.; Galie, N.; Grimminger, F.; Grunig, E.; Humbert, M.; Jing, Z.C.; Keogh, A.M.; Langleben, D.; Kilama, M.O.; Fritsch, A.; et al. Riociguat for the treatment of pulmonary arterial hypertension. N. Engl. J. Med. 2013, 369, 330-340. [CrossRef]

18. Sugimura, K.; Fukumoto, Y.; Satoh, K.; Nochioka, K.; Miura, Y.; Aoki, T.; Tatebe, S.; Miyamichi-Yamamoto, S.; Shimokawa, H. Percutaneous transluminal pulmonary angioplasty markedly improves pulmonary hemodynamics and long-term prognosis in patients with chronic thromboembolic pulmonary hypertension. Circ. J. 2012, 76, 485-488. [CrossRef]

19. Kimura, M.; Kohno, T.; Kawakami, T.; Kataoka, M.; Inohara, T.; Takei, M.; Tsugu, T.; Murata, M.; Maekawa, Y.; Fukuda, K. Balloon pulmonary angioplasty attenuates ongoing myocardial damage in patients with chronic thromboembolic pulmonary hypertension. Int. J. Cardiol. 2016, 207, 387-389. [CrossRef] [PubMed] 
20. Ogo, T.; Fukuda, T.; Tsuji, A.; Fukui, S.; Ueda, J.; Sanda, Y.; Morita, Y.; Asano, R.; Konagai, N.; Yasuda, S. Efficacy and safety of balloon pulmonary angioplasty for chronic thromboembolic pulmonary hypertension guided by cone-beam computed tomography and electrocardiogram-gated area detector computed tomography. Eur. J. Radiol. 2017, 89, 270-276. [CrossRef]

21. Yamasaki, Y.; Nagao, M.; Abe, K.; Hosokawa, K.; Kawanami, S.; Kamitani, T.; Yamanouchi, T.; Horimoto, K.; Yabuuchi, H.; Honda, $\mathrm{H}$. Balloon pulmonary angioplasty improves interventricular dyssynchrony in patients with inoperable chronic thromboembolic pulmonary hypertension: A cardiac MR imaging study. Int. J. Cardiovasc. Imaging 2017, 33, 229-239. [CrossRef] [PubMed]

22. Aoki, T.; Sugimura, K.; Nochioka, K.; Miura, M.; Tatebe, S.; Yamamoto, S.; Yaoita, N.; Suzuki, H.; Sato, H.; Kozu, K.; et al. Effects of Balloon Pulmonary Angioplasty on Oxygenation in Patients With Chronic Thromboembolic Pulmonary HypertensionImportance of Intrapulmonary Shunt. Circ. J. 2016, 80, 2227-2234. [CrossRef]

23. Inami, T.; Kataoka, M.; Shimura, N.; Ishiguro, H.; Yanagisawa, R.; Fukuda, K.; Yoshino, H.; Satoh, T. Pressure-wire-guided percutaneous transluminal pulmonary angioplasty: A breakthrough in catheter-interventional therapy for chronic thromboembolic pulmonary hypertension. JACC Cardiovasc. Interv. 2014, 7, 1297-1306. [CrossRef] [PubMed]

24. Kurzyna, M.; Darocha, S.; Pietura, R.; Pietrasik, A.; Norwa, J.; Manczak, R.; Wieteska, M.; Biederman, A.; Matsubara, H.; Torbicki, A. Changing the strategy of balloon pulmonary angioplasty resulted in a reduced complication rate in patients with chronic thromboembolic pulmonary hypertension. A single-centre European experience. Kardiol. Pol. 2017, 75, 645-654. [CrossRef]

25. Olsson, K.M.; Wiedenroth, C.B.; Kamp, J.C.; Breithecker, A.; Fuge, J.; Krombach, G.A.; Haas, M.; Hamm, C.; Kramm, T.; Guth, S.; et al. Balloon pulmonary angioplasty for inoperable patients with chronic thromboembolic pulmonary hypertension: The initial German experience. Eur. Respir. J. 2017, 49, 1602409. [CrossRef] [PubMed]

26. Araszkiewicz, A.; Darocha, S.; Pietrasik, A.; Pietura, R.; Jankiewicz, S.; Banaszkiewicz, M.; Slawek-Szmyt, S.; Biederman, A.; Mularek-Kubzdela, T.; Lesiak, M.; et al. Balloon pulmonary angioplasty for the treatment of residual or recurrent pulmonary hypertension after pulmonary endarterectomy. Int. J. Cardiol. 2019, 278, 232-237. [CrossRef] [PubMed]

27. Darocha, S.; Araszkiewicz, A.; Kurzyna, M.; Banaszkiewicz, M.; Jankiewicz, S.; Dobosiewicz, A.; Slawek-Szmyt, S.; Janus, M.; Grymuza, M.; Pietrasik, A.; et al. Balloon Pulmonary Angioplasty in Technically Operable and Technically Inoperable Chronic Thromboembolic Pulmonary Hypertension. J. Clin. Med. 2021, 10, 1038. [CrossRef]

28. Gerges, C.; Friewald, R.; Gerges, M.; Shafran, I.; Sadushi-Kolici, R.; Skoro-Sajer, N.; Moser, B.; Taghavi, S.; Klepetko, W.; Lang, I.M. Efficacy and Safety of Percutaneous Pulmonary Artery Subtotal Occlusion and Chronic Total Occlusion Intervention in Chronic Thromboembolic Pulmonary Hypertension. Circ. Cardiovasc. Interv. 2021, 14, e010243. [CrossRef]

29. Collet, J.P.; Thiele, H.; Barbato, E.; Barthelemy, O.; Bauersachs, J.; Bhatt, D.L.; Dendale, P.; Dorobantu, M.; Edvardsen, T.; Folliguet, T.; et al. 2020 ESC Guidelines for the management of acute coronary syndromes in patients presenting without persistent ST-segment elevation. Rev. Esp. Cardiol. 2021, 74, 544. [CrossRef]

30. Eggers, K.M.; Lagerqvist, B.; Venge, P.; Wallentin, L.; Lindahl, B. Persistent cardiac troponin I elevation in stabilized patients after an episode of acute coronary syndrome predicts long-term mortality. Circulation 2007, 116, 1907-1914. [CrossRef]

31. de Lemos, J.A.; Drazner, M.H.; Omland, T.; Ayers, C.R.; Khera, A.; Rohatgi, A.; Hashim, I.; Berry, J.D.; Das, S.R.; Morrow, D.A.; et al. Association of troponin $\mathrm{T}$ detected with a highly sensitive assay and cardiac structure and mortality risk in the general population. JAMA 2010, 304, 2503-2512. [CrossRef] [PubMed]

32. Apple, F.S.; Murakami, M.M.; Pearce, L.A.; Herzog, C.A. Predictive value of cardiac troponin I and T for subsequent death in end-stage renal disease. Circulation 2002, 106, 2941-2945. [CrossRef] [PubMed]

33. Horwich, T.B.; Patel, J.; MacLellan, W.R.; Fonarow, G.C. Cardiac troponin I is associated with impaired hemodynamics, progressive left ventricular dysfunction, and increased mortality rates in advanced heart failure. Circulation 2003, 108, 833-838. [CrossRef] [PubMed]

34. Velez-Martinez, M.; Ayers, C.; Mishkin, J.D.; Bartolome, S.B.; Garcia, C.K.; Torres, F.; Drazner, M.H.; de Lemos, J.A.; Turer, A.T.; Chin, K.M. Association of cardiac troponin I with disease severity and outcomes in patients with pulmonary hypertension. Am. J. Cardiol. 2013, 111, 1812-1817. [CrossRef] [PubMed]

35. Torbicki, A.; Kurzyna, M.; Kuca, P.; Fijalkowska, A.; Sikora, J.; Florczyk, M.; Pruszczyk, P.; Burakowski, J.; Wawrzynska, L. Detectable serum cardiac troponin $\mathrm{T}$ as a marker of poor prognosis among patients with chronic precapillary pulmonary hypertension. Circulation 2003, 108, 844-848. [CrossRef] [PubMed]

36. Heresi, G.A.; Tang, W.H.; Aytekin, M.; Hammel, J.; Hazen, S.L.; Dweik, R.A. Sensitive cardiac troponin I predicts poor outcomes in pulmonary arterial hypertension. Eur. Respir. J. 2012, 39, 939-944. [CrossRef]

37. Kriechbaum, S.D.; Wiedenroth, C.B.; Keller, T.; Wolter, J.S.; Ajnwojner, R.; Peters, K.; Haas, M.A.; Roller, F.C.; Breithecker, A.; Rieth, A.J.; et al. Dynamics of high-sensitivity cardiac troponin T during therapy with balloon pulmonary angioplasty for chronic thromboembolic pulmonary hypertension. PLoS ONE 2018, 13, e0204683. [CrossRef]

38. Weinberg, E.O.; Shimpo, M.; De Keulenaer, G.W.; MacGillivray, C.; Tominaga, S.; Solomon, S.D.; Rouleau, J.L.; Lee, R.T. Expression and regulation of ST2, an interleukin-1 receptor family member, in cardiomyocytes and myocardial infarction. Circulation 2002, 106, 2961-2966. [CrossRef]

39. Sanada, S.; Hakuno, D.; Higgins, L.J.; Schreiter, E.R.; McKenzie, A.N.; Lee, R.T. IL-33 and ST2 comprise a critical biomechanically induced and cardioprotective signaling system. J. Clin. Investig. 2007, 117, 1538-1549. [CrossRef]

40. Januzzi, J.L., Jr.; Peacock, W.F.; Maisel, A.S.; Chae, C.U.; Jesse, R.L.; Baggish, A.L.; O’Donoghue, M.; Sakhuja, R.; Chen, A.A.; van Kimmenade, R.R.; et al. Measurement of the interleukin family member ST2 in patients with acute dyspnea: Results from the 
PRIDE (Pro-Brain Natriuretic Peptide Investigation of Dyspnea in the Emergency Department) study. J. Am. Coll. Cardiol. 2007, 50, 607-613. [CrossRef]

41. Dieplinger, B.; Mueller, T. Soluble ST2 in heart failure. Clin. Chim. Acta 2015, 443, 57-70. [CrossRef]

42. Ky, B.; French, B.; McCloskey, K.; Rame, J.E.; McIntosh, E.; Shahi, P.; Dries, D.L.; Tang, W.H.; Wu, A.H.; Fang, J.C.; et al. High-sensitivity ST2 for prediction of adverse outcomes in chronic heart failure. Circ. Heart Fail. 2011, 4, 180-187. [CrossRef]

43. Pascual-Figal, D.A.; Manzano-Fernandez, S.; Boronat, M.; Casas, T.; Garrido, I.P.; Bonaque, J.C.; Pastor-Perez, F.; Valdes, M.; Januzzi, J.L. Soluble ST2, high-sensitivity troponin T- and N-terminal pro-B-type natriuretic peptide: Complementary role for risk stratification in acutely decompensated heart failure. Eur. J. Heart Fail. 2011, 13, 718-725. [CrossRef]

44. Felker, G.M.; Fiuzat, M.; Thompson, V.; Shaw, L.K.; Neely, M.L.; Adams, K.F.; Whellan, D.J.; Donahue, M.P.; Ahmad, T.; Kitzman, D.W.; et al. Soluble ST2 in ambulatory patients with heart failure: Association with functional capacity and long-term outcomes. Circ. Heart Fail. 2013, 6, 1172-1179. [CrossRef]

45. Lassus, J.; Gayat, E.; Mueller, C.; Peacock, W.F.; Spinar, J.; Harjola, V.P.; van Kimmenade, R.; Pathak, A.; Mueller, T.; Disomma, S.; et al. Incremental value of biomarkers to clinical variables for mortality prediction in acutely decompensated heart failure: The Multinational Observational Cohort on Acute Heart Failure (MOCA) study. Int. J. Cardiol. 2013, 168, 2186-2194. [CrossRef]

46. Lu, J.; Snider, J.V.; Grenache, D.G. Establishment of reference intervals for soluble ST2 from a United States population. Clin. Chim. Acta 2010, 411, 1825-1826. [CrossRef] [PubMed]

47. Carlomagno, G.; Messalli, G.; Melillo, R.M.; Stanziola, A.A.; Visciano, C.; Mercurio, V.; Imbriaco, M.; Ghio, S.; Sofia, M.; Bonaduce, D.; et al. Serum soluble ST2 and interleukin-33 levels in patients with pulmonary arterial hypertension. Int. J. Cardiol. 2013, 168, 1545-1547. [CrossRef] [PubMed]

48. Banaszkiewicz, M.; Pietrasik, A.; Darocha, S.; Piłka, M.; Florczyk, M.; Dobosiewicz, A.; Kędzierski, P.; Pędzich-Placha, E.; Kochman, J.; Opolski, G.; et al. Soluble ST2 protein as a new biomarker in patientswith precapillary pulmonary hypertension. Arch. Med. Sci. 2020. [CrossRef]

49. Geenen, L.W.; Baggen, V.J.M.; Kauling, R.M.; Koudstaal, T.; Boomars, K.A.; Boersma, E.; Roos-Hesselink, J.W.; van den Bosch, A.E. The Prognostic Value of Soluble ST2 in Adults with Pulmonary Hypertension. J. Clin. Med. 2019, 8, 1517. [CrossRef]

50. Zheng, Y.G.; Yang, T.; He, J.G.; Chen, G.; Liu, Z.H.; Xiong, C.M.; Gu, Q.; Ni, X.H.; Zhao, Z.H. Plasma soluble ST2 levels correlate with disease severity and predict clinical worsening in patients with pulmonary arterial hypertension. Clin. Cardiol. 2014, 37, 365-370. [CrossRef]

51. Kriechbaum, S.D.; Wiedenroth, C.B.; Peters, K.; Barde, M.A.; Ajnwojner, R.; Wolter, J.S.; Haas, M.; Roller, F.C.; Guth, S.; Rieth, A.J.; et al. Galectin-3, GDF-15, and sST2 for the assessment of disease severity and therapy response in patients suffering from inoperable chronic thromboembolic pulmonary hypertension. Biomarkers 2020, 25, 578-586. [CrossRef]

52. Banaszkiewicz, M.; Pietrasik, A.; Florczyk, M.; Kedzierski, P.; Pilka, M.; Manczak, R.; Kochman, J.; Opolski, G.; Torbicki, A.; Kurzyna, M.; et al. Soluble ST2 as a Biomarker for Early Complications in Patients with Chronic Thromboembolic Pulmonary Hypertension Treated with Balloon Pulmonary Angioplasty. Diagnostics 2021, 11, 133. [CrossRef]

53. Carroll, C.; Al Khalaf, M.; Stevens, J.W.; Leaviss, J.; Goodacre, S.; Collinson, P.O.; Wang, J. Heart-type fatty acid binding protein as an early marker for myocardial infarction: Systematic review and meta-analysis. Emerg. Med. J. 2013, 30, 280-286. [CrossRef]

54. Puls, M.; Dellas, C.; Lankeit, M.; Olschewski, M.; Binder, L.; Geibel, A.; Reiner, C.; Schafer, K.; Hasenfuss, G.; Konstantinides, S. Heart-type fatty acid-binding protein permits early risk stratification of pulmonary embolism. Eur. Heart J. 2007, 28, 224-229. [CrossRef]

55. Lankeit, M.; Dellas, C.; Panzenbock, A.; Skoro-Sajer, N.; Bonderman, D.; Olschewski, M.; Schafer, K.; Puls, M.; Konstantinides, S.; Lang, I.M. Heart-type fatty acid-binding protein for risk assessment of chronic thromboembolic pulmonary hypertension. Eur. Respir. J. 2008, 31, 1024-1029. [CrossRef]

56. Mirna, M.; Rohm, I.; Jirak, P.; Wernly, B.; Baz, L.; Paar, V.; Kretzschmar, D.; Hoppe, U.C.; Schulze, P.C.; Lichtenauer, M.; et al. Analysis of Novel Cardiovascular Biomarkers in Patients With Pulmonary Hypertension (PH). Heart Lung Circ. 2020, 29, 337-344. [CrossRef] [PubMed]

57. Quarck, R.; Nawrot, T.; Meyns, B.; Delcroix, M. C-reactive protein: A new predictor of adverse outcome in pulmonary arterial hypertension. J. Am. Coll. Cardiol. 2009, 53, 1211-1218. [CrossRef] [PubMed]

58. Scognamiglio, G.; Kempny, A.; Price, L.C.; Alonso-Gonzalez, R.; Marino, P.; Swan, L.; D'Alto, M.; Hooper, J.; Gatzoulis, M.A.; Dimopoulos, K.; et al. C-reactive protein in adults with pulmonary arterial hypertension associated with congenital heart disease and its prognostic value. Heart 2014, 100, 1335-1341. [CrossRef] [PubMed]

59. Wynants, M.; Quarck, R.; Ronisz, A.; Alfaro-Moreno, E.; Van Raemdonck, D.; Meyns, B.; Delcroix, M. Effects of C-reactive protein on human pulmonary vascular cells in chronic thromboembolic pulmonary hypertension. Eur. Respir. J. 2012, 40, 886-894. [CrossRef]

60. Yang, M.; Deng, C.; Wu, D.; Zhong, Z.; Lv, X.; Huang, Z.; Lian, N.; Liu, K.; Zhang, Q. The role of mononuclear cell tissue factor and inflammatory cytokines in patients with chronic thromboembolic pulmonary hypertension. J. Thromb. Thrombolysis 2016, 42, 38-45. [CrossRef]

61. Lippi, G.; Targher, G.; Montagnana, M.; Salvagno, G.L.; Zoppini, G.; Guidi, G.C. Relation between red blood cell distribution width and inflammatory biomarkers in a large cohort of unselected outpatients. Arch. Pathol. Lab. Med. 2009, 133, 628-632. [CrossRef] 
62. Osadnik, T.; Strzelczyk, J.; Hawranek, M.; Lekston, A.; Wasilewski, J.; Kurek, A.; Gutowski, A.R.; Wilczek, K.; Dyrbus, K.; Gierlotka, M.; et al. Red cell distribution width is associated with long-term prognosis in patients with stable coronary artery disease. BMC Cardiovasc. Disord. 2013, 13, 113. [CrossRef]

63. Felker, G.M.; Allen, L.A.; Pocock, S.J.; Shaw, L.K.; McMurray, J.J.; Pfeffer, M.A.; Swedberg, K.; Wang, D.; Yusuf, S.; Michelson, E.L.; et al. Red cell distribution width as a novel prognostic marker in heart failure: Data from the CHARM Program and the Duke Databank. J. Am. Coll. Cardiol. 2007, 50, 40-47. [CrossRef]

64. Zorlu, A.; Bektasoglu, G.; Guven, F.M.; Dogan, O.T.; Gucuk, E.; Ege, M.R.; Altay, H.; Cinar, Z.; Tandogan, I.; Yilmaz, M.B. Usefulness of admission red cell distribution width as a predictor of early mortality in patients with acute pulmonary embolism. Am. J. Cardiol. 2012, 109, 128-134. [CrossRef]

65. Rhodes, C.J.; Wharton, J.; Howard, L.S.; Gibbs, J.S.; Wilkins, M.R. Red cell distribution width outperforms other potential circulating biomarkers in predicting survival in idiopathic pulmonary arterial hypertension. Heart 2011, 97, 1054-1060. [CrossRef]

66. Hampole, C.V.; Mehrotra, A.K.; Thenappan, T.; Gomberg-Maitland, M.; Shah, S.J. Usefulness of red cell distribution width as a prognostic marker in pulmonary hypertension. Am. J. Cardiol. 2009, 104, 868-872. [CrossRef]

67. Smukowska-Gorynia, A.; Tomaszewska, I.; Malaczynska-Rajpold, K.; Marcinkowska, J.; Komosa, A.; Janus, M.; OlasinskaWisniewska, A.; Slawek, S.; Araszkiewicz, A.; Jankiewicz, S.; et al. Red Blood Cells Distribution Width as a Potential Prognostic Biomarker in Patients With Pulmonary Arterial Hypertension and Chronic Thromboembolic Pulmonary Hypertension. Heart Lung Circ. 2018, 27, 842-848. [CrossRef]

68. Wang, W.; Liu, J.; Yang, Y.H.; Zhai, Z.G.; Wang, C.; Wang, J. Red cell distribution width is increased in chronic thromboembolic pulmonary hypertension. Clin. Respir. J. 2016, 10, 54-60. [CrossRef]

69. Nickel, N.; Jonigk, D.; Kempf, T.; Bockmeyer, C.L.; Maegel, L.; Rische, J.; Laenger, F.; Lehmann, U.; Sauer, C.; Greer, M.; et al GDF-15 is abundantly expressed in plexiform lesions in patients with pulmonary arterial hypertension and affects proliferation and apoptosis of pulmonary endothelial cells. Respir. Res. 2011, 12, 62. [CrossRef]

70. Mueller, T.; Leitner, I.; Egger, M.; Haltmayer, M.; Dieplinger, B. Association of the biomarkers soluble ST2, galectin-3 and growth-differentiation factor-15 with heart failure and other non-cardiac diseases. Clin. Chim. Acta 2015, 445, 155-160. [CrossRef] [PubMed]

71. Wollert, K.C.; Kempf, T.; Wallentin, L. Growth Differentiation Factor 15 as a Biomarker in Cardiovascular Disease. Clin. Chim. 2017, 63, 140-151. [CrossRef] [PubMed]

72. Nickel, N.; Kempf, T.; Tapken, H.; Tongers, J.; Laenger, F.; Lehmann, U.; Golpon, H.; Olsson, K.; Wilkins, M.R.; Gibbs, J.S.; et al. Growth differentiation factor-15 in idiopathic pulmonary arterial hypertension. Am. J. Respir. Crit. Care Med. 2008, 178, 534-541. [CrossRef]

73. Meadows, C.A.; Risbano, M.G.; Zhang, L.; Geraci, M.W.; Tuder, R.M.; Collier, D.H.; Bull, T.M. Increased expression of growth differentiation factor-15 in systemic sclerosis-associated pulmonary arterial hypertension. Chest 2011, 139, 994-1002. [CrossRef] [PubMed]

74. Soon, E.; Holmes, A.M.; Treacy, C.M.; Doughty, N.J.; Southgate, L.; Machado, R.D.; Trembath, R.C.; Jennings, S.; Barker, L.; Nicklin, P.; et al. Elevated levels of inflammatory cytokines predict survival in idiopathic and familial pulmonary arterial hypertension. Circulation 2010, 122, 920-927. [CrossRef] [PubMed]

75. Selimovic, N.; Bergh, C.H.; Andersson, B.; Sakiniene, E.; Carlsten, H.; Rundqvist, B. Growth factors and interleukin-6 across the lung circulation in pulmonary hypertension. Eur. Respir. J. 2009, 34, 662-668. [CrossRef] [PubMed]

76. Langer, F.; Schramm, R.; Bauer, M.; Tscholl, D.; Kunihara, T.; Schafers, H.J. Cytokine response to pulmonary thromboendarterectomy. Chest 2004, 126, 135-141. [CrossRef] [PubMed]

77. Zabini, D.; Heinemann, A.; Foris, V.; Nagaraj, C.; Nierlich, P.; Balint, Z.; Kwapiszewska, G.; Lang, I.M.; Klepetko, W.; Olschewski, H.; et al. Comprehensive analysis of inflammatory markers in chronic thromboembolic pulmonary hypertension patients. Eur. Respir. J. 2014, 44, 951-962. [CrossRef]

78. Nathan, C.F. Peroxide and pteridine: A hypothesis on the regulation of macrophage antimicrobial activity by interferon gamma Interferon 1986, 7, 125-143. [PubMed]

79. Hoffmann, G.; Wirleitner, B.; Fuchs, D. Potential role of immune system activation-associated production of neopterin derivatives in humans. Inflamm. Res. 2003, 52, 313-321. [CrossRef]

80. Yamamoto, E.; Hirata, Y.; Tokitsu, T.; Kusaka, H.; Tabata, N.; Tsujita, K.; Yamamuro, M.; Kaikita, K.; Watanabe, H.; Hokimoto, S.; et al. The clinical significance of plasma neopterin in heart failure with preserved left ventricular ejection fraction. ESC Heart Fail. 2016, 3, 53-59. [CrossRef] [PubMed]

81. Ray, K.K.; Morrow, D.A.; Sabatine, M.S.; Shui, A.; Rifai, N.; Cannon, C.P.; Braunwald, E. Long-term prognostic value of neopterin A novel marker of monocyte activation in patients with acute coronary syndrome. Circulation 2007, 115, 3071-3078. [CrossRef] [PubMed]

82. Smukowska-Gorynia, A.; Marcinkowska, J.; Chmara, E.; Malaczynska-Rajpold, K.; Slawek-Szmyt, S.; Cieslewicz, A.; Janus, M.; Araszkiewicz, A.; Jankiewicz, S.; Komosa, A.; et al. Neopterin as a Biomarker in Patients with Pulmonary Arterial Hypertension and Chronic Thromboembolic Pulmonary Hypertension. Respiration 2018, 96, 222-230. [CrossRef]

83. Meijers, W.C.; van der Velde, A.R.; Pascual-Figal, D.A.; de Boer, R.A. Galectin-3 and post-myocardial infarction cardiac remodeling. Eur. J. Pharmacol. 2015, 763, 115-121. [CrossRef] [PubMed] 
84. Yang, R.Y.; Rabinovich, G.A.; Liu, F.T. Galectins: Structure, function and therapeutic potential. Expert Rev. Mol. Med. 2008, 10, e17. [CrossRef]

85. de Boer, R.A.; Voors, A.A.; Muntendam, P.; van Gilst, W.H.; van Veldhuisen, D.J. Galectin-3: A novel mediator of heart failure development and progression. Eur. J. Heart Fail. 2009, 11, 811-817. [CrossRef]

86. Meijers, W.C.; Januzzi, J.L.; deFilippi, C.; Adourian, A.S.; Shah, S.J.; van Veldhuisen, D.J.; de Boer, R.A. Elevated plasma galectin-3 is associated with near-term rehospitalization in heart failure: A pooled analysis of 3 clinical trials. Am. Heart J. 2014, 167, 853-860. [CrossRef] [PubMed]

87. Gullestad, L.; Ueland, T.; Kjekshus, J.; Nymo, S.H.; Hulthe, J.; Muntendam, P.; McMurray, J.J.; Wikstrand, J.; Aukrust, P. The predictive value of galectin-3 for mortality and cardiovascular events in the Controlled Rosuvastatin Multinational Trial in Heart Failure (CORONA). Am. Heart J. 2012, 164, 878-883. [CrossRef]

88. van der Velde, A.R.; Gullestad, L.; Ueland, T.; Aukrust, P.; Guo, Y.; Adourian, A.; Muntendam, P.; van Veldhuisen, D.J.; de Boer R.A. Prognostic value of changes in galectin-3 levels over time in patients with heart failure: Data from $\mathrm{CORONA}$ and $\mathrm{COACH}$. Circ. Heart Fail. 2013, 6, 219-226. [CrossRef] [PubMed]

89. Fenster, B.E.; Lasalvia, L.; Schroeder, J.D.; Smyser, J.; Silveira, L.J.; Buckner, J.K.; Brown, K.K. Galectin-3 levels are associated with right ventricular functional and morphologic changes in pulmonary arterial hypertension. Heart Vessels 2016, 31, 939-946. [CrossRef]

90. Calvier, L.; Legchenko, E.; Grimm, L.; Sallmon, H.; Hatch, A.; Plouffe, B.D.; Schroeder, C.; Bauersachs, J.; Murthy, S.K.; Hansmann, G. Galectin-3 and aldosterone as potential tandem biomarkers in pulmonary arterial hypertension. Heart 2016, 102, 390-396. [CrossRef] [PubMed]

91. Mazurek, J.A.; Horne, B.D.; Saeed, W.; Sardar, M.R.; Zolty, R. Galectin-3 Levels Are Elevated and Predictive of Mortality in Pulmonary Hypertension. Heart Lung Circ. 2017, 26, 1208-1215. [CrossRef]

92. Geenen, L.W.; Baggen, V.J.M.; Koudstaal, T.; Boomars, K.A.; Eindhoven, J.A.; Boersma, E.; Roos-Hesselink, J.W.; van den Bosch, A.E. The prognostic value of various biomarkers in adults with pulmonary hypertension; a multi-biomarker approach. Am. Heart J. 2019, 208, 91-99. [CrossRef] [PubMed]

93. Zhang, S.; Yang, T.; Xu, X.; Wang, M.; Zhong, L.; Yang, Y.; Zhai, Z.; Xiao, F.; Wang, C. Oxidative stress and nitric oxide signaling related biomarkers in patients with pulmonary hypertension: A case control study. BMC Pulm. Med. 2015, 15, 50. [CrossRef] [PubMed]

94. Gasecka, A.; Szwed, P.; Jasinska, K.; Fidali, O.; Klebukowska, A.; Eyileten, C.; Postula, M.; Szarpak, L.; Mazurek, T.; Opolski, G.; et al. Symmetric Dimethylarginine is Altered in Patients After Myocardial Infarction and Predicts Adverse Outcomes. J. Inflamm. Res. 2021, 14, 3797-3808. [CrossRef]

95. Kielstein, J.T.; Bode-Boger, S.M.; Hesse, G.; Martens-Lobenhoffer, J.; Takacs, A.; Fliser, D.; Hoeper, M.M. Asymmetrical dimethylarginine in idiopathic pulmonary arterial hypertension. Arterioscler. Thromb. Vasc. Biol. 2005, 25, 1414-1418. [CrossRef] [PubMed]

96. Skoro-Sajer, N.; Mittermayer, F.; Panzenboeck, A.; Bonderman, D.; Sadushi, R.; Hitsch, R.; Jakowitsch, J.; Klepetko, W.; Kneussl, M.P.; Wolzt, M.; et al. Asymmetric dimethylarginine is increased in chronic thromboembolic pulmonary hypertension. Am. J. Respir. Crit. Care Med. 2007, 176, 1154-1160. [CrossRef] [PubMed]

97. Sanli, C.; Oguz, D.; Olgunturk, R.; Tunaoglu, F.S.; Kula, S.; Pasaoglu, H.; Gulbahar, O.; Cevik, A. Elevated homocysteine and asymmetric dimethyl arginine levels in pulmonary hypertension associated with congenital heart disease. Pediatr. Cardiol. 2012, 33, 1323-1331. [CrossRef]

98. Giaid, A.; Yanagisawa, M.; Langleben, D.; Michel, R.P.; Levy, R.; Shennib, H.; Kimura, S.; Masaki, T.; Duguid, W.P.; Stewart, D.J. Expression of endothelin-1 in the lungs of patients with pulmonary hypertension. N. Engl. J. Med. 1993, 328, 1732-1739. [CrossRef]

99. Meoli, D.F.; White, R.J. Endothelin-1 induces pulmonary but not aortic smooth muscle cell migration by activating ERK1/2 MAP kinase. Can. J. Physiol. Pharmacol. 2010, 88, 830-839. [CrossRef] [PubMed]

100. Shao, D.; Park, J.E.; Wort, S.J. The role of endothelin-1 in the pathogenesis of pulmonary arterial hypertension. Pharmacol. Res. 2011, 63, 504-511. [CrossRef]

101. Rubens, C.; Ewert, R.; Halank, M.; Wensel, R.; Orzechowski, H.D.; Schultheiss, H.P.; Hoeffken, G. Big endothelin-1 and endothelin1 plasma levels are correlated with the severity of primary pulmonary hypertension. Chest 2001, 120, 1562-1569. [CrossRef] [PubMed]

102. Langer, F.; Bauer, M.; Tscholl, D.; Schramm, R.; Kunihara, T.; Lausberg, H.; Georg, T.; Wilkens, H.; Schafers, H.J. Circulating big endothelin-1: An active role in pulmonary thromboendarterectomy? J. Thorac. Cardiovasc. Surg. 2005, 130, 1342-1347. [CrossRef]

103. Reesink, H.J.; Meijer, R.C.; Lutter, R.; Boomsma, F.; Jansen, H.M.; Kloek, J.J.; Bresser, P. Hemodynamic and clinical correlates of endothelin-1 in chronic thromboembolic pulmonary hypertension. Circ. J. 2006, 70, 1058-1063. [CrossRef] [PubMed]

104. Cacoub, P.; Dorent, R.; Nataf, P.; Carayon, A.; Riquet, M.; Noe, E.; Piette, J.C.; Godeau, P.; Gandjbakhch, I. Endothelin-1 in the lungs of patients with pulmonary hypertension. Cardiovasc. Res. 1997, 33, 196-200. [CrossRef]

105. Struck, J.; Morgenthaler, N.G.; Bergmann, A. Proteolytic processing pattern of the endothelin-1 precursor in vivo. Peptides 2005, 26, 2482-2486. [CrossRef] [PubMed] 
106. Silva Marques, J.; Martins, S.R.; Calisto, C.; Goncalves, S.; Almeida, A.G.; de Sousa, J.C.; Pinto, F.J.; Diogo, A.N. An exploratory panel of biomarkers for risk prediction in pulmonary hypertension: Emerging role of CT-proET-1. J. Heart Lung Transplant. 2013, 32, 1214-1221. [CrossRef]

107. Bartel, D.P. MicroRNAs: Genomics, biogenesis, mechanism, and function. Cell 2004, 116, 281-297. [CrossRef]

108. Wang, G.K.; Zhu, J.Q.; Zhang, J.T.; Li, Q.; Li, Y.; He, J.; Qin, Y.W.; Jing, Q. Circulating microRNA: A novel potential biomarker for early diagnosis of acute myocardial infarction in humans. Eur. Heart J. 2010, 31, 659-666. [CrossRef]

109. Di Stefano, V.; Zaccagnini, G.; Capogrossi, M.C.; Martelli, F. microRNAs as peripheral blood biomarkers of cardiovascular disease. Vasc. Pharmacol. 2011, 55, 111-118. [CrossRef]

110. Lee, A.; McLean, D.; Choi, J.; Kang, H.; Chang, W.; Kim, J. Therapeutic implications of microRNAs in pulmonary arterial hypertension. BMB Rep. 2014, 47, 311-317. [CrossRef] [PubMed]

111. Rothman, A.M.; Arnold, N.D.; Pickworth, J.A.; Iremonger, J.; Ciuclan, L.; Allen, R.M.; Guth-Gundel, S.; Southwood, M.; Morrell, N.W.; Thomas, M.; et al. MicroRNA-140-5p and SMURF1 regulate pulmonary arterial hypertension. J. Clin. Investig. 2016, 126, 2495-2508. [CrossRef] [PubMed]

112. Sarrion, I.; Milian, L.; Juan, G.; Ramon, M.; Furest, I.; Carda, C.; Cortijo Gimeno, J.; Mata Roig, M. Role of circulating miRNAs as biomarkers in idiopathic pulmonary arterial hypertension: Possible relevance of miR-23a. Oxid. Med. Cell Longev. 2015, 2015, 792846. [CrossRef] [PubMed]

113. Hoeper, M.M.; Pletz, M.W.; Golpon, H.; Welte, T. Prognostic value of blood gas analyses in patients with idiopathic pulmonary arterial hypertension. Eur. Respir. J. 2007, 29, 944-950. [CrossRef]

114. Valentin, S.; Maurac, A.; Sitbon, O.; Beurnier, A.; Gomez, E.; Guillaumot, A.; Textoris, L.; Fay, R.; Savale, L.; Jais, X.; et al. Outcomes of patients with decreased arterial oxyhaemoglobin saturation on pulmonary arterial hypertension drugs. Eur. Respir. J. 2021, 58. [CrossRef]

115. American Thoracic Society. ATS/ACCP Statement on cardiopulmonary exercise testing. Am. J. Respir. Crit. Care Med. 2003, 167, 211-277. [CrossRef]

116. Weatherald, J.; Farina, S.; Bruno, N.; Laveneziana, P. Cardiopulmonary Exercise Testing in Pulmonary Hypertension. Ann. Am. Thorac. Soc. 2017, 14, S84-S92. [CrossRef]

117. Hoeper, M.M.; Hohlfeld, J.M.; Fabel, H. Hyperuricaemia in patients with right or left heart failure. Eur. Respir. J. 1999, 13, 682-685. [CrossRef]

118. Nagaya, N.; Uematsu, M.; Satoh, T.; Kyotani, S.; Sakamaki, F.; Nakanishi, N.; Yamagishi, M.; Kunieda, T.; Miyatake, K. Serum uric acid levels correlate with the severity and the mortality of primary pulmonary hypertension. Am. J. Respir. Crit. Care Med. 1999, 160, 487-492. [CrossRef] [PubMed]

119. Voelkel, M.A.; Wynne, K.M.; Badesch, D.B.; Groves, B.M.; Voelkel, N.F. Hyperuricemia in severe pulmonary hypertension. Chest 2000, 117, 19-24. [CrossRef] [PubMed]

120. Wang, J.; Wang, Y.; Li, X.; Huang, Y.; Sun, X.; Wang, Q.; Zhang, M. Serum uric acid is associated with disease severity and may predict clinical outcome in patients of pulmonary arterial hypertension secondary to connective tissue disease in Chinese: A single-center retrospective study. BMC Pulm. Med. 2020, 20, 272. [CrossRef] [PubMed]

121. Van Albada, M.E.; Loot, F.G.; Fokkema, R.; Roofthooft, M.T.; Berger, R.M. Biological serum markers in the management of pediatric pulmonary arterial hypertension. Pediatr. Res. 2008, 63, 321-327. [CrossRef] [PubMed]

122. Keller, T.; Tzikas, S.; Zeller, T.; Czyz, E.; Lillpopp, L.; Ojeda, F.M.; Roth, A.; Bickel, C.; Baldus, S.; Sinning, C.R.; et al. Copeptin improves early diagnosis of acute myocardial infarction. J. Am. Coll. Cardiol. 2010, 55, 2096-2106. [CrossRef] [PubMed]

123. Neuhold, S.; Huelsmann, M.; Strunk, G.; Stoiser, B.; Struck, J.; Morgenthaler, N.G.; Bergmann, A.; Moertl, D.; Berger, R.; Pacher, R Comparison of copeptin, B-type natriuretic peptide, and amino-terminal pro-B-type natriuretic peptide in patients with chronic heart failure: Prediction of death at different stages of the disease. J. Am. Coll. Cardiol. 2008, 52, 266-272. [CrossRef] [PubMed]

124. Morgenthaler, N.G.; Struck, J.; Jochberger, S.; Dunser, M.W. Copeptin: Clinical use of a new biomarker. Trends Endocrinol. Metab. 2008, 19, 43-49. [CrossRef]

125. Alehagen, U.; Dahlstrom, U.; Rehfeld, J.F.; Goetze, J.P. Association of copeptin and N-terminal proBNP concentrations with risk of cardiovascular death in older patients with symptoms of heart failure. JAMA 2011, 305, 2088-2095. [CrossRef] [PubMed]

126. D'Alonzo, G.E.; Barst, R.J.; Ayres, S.M.; Bergofsky, E.H.; Brundage, B.H.; Detre, K.M.; Fishman, A.P.; Goldring, R.M.; Groves, B.M.; Kernis, J.T.; et al. Survival in patients with primary pulmonary hypertension. Results from a national prospective registry. Ann. Intern. Med. 1991, 115, 343-349. [CrossRef]

127. Shah, S.J.; Thenappan, T.; Rich, S.; Tian, L.; Archer, S.L.; Gomberg-Maitland, M. Association of serum creatinine with abnormal hemodynamics and mortality in pulmonary arterial hypertension. Circulation 2008, 117, 2475-2483. [CrossRef]

128. Benza, R.L.; Miller, D.P.; Gomberg-Maitland, M.; Frantz, R.P.; Foreman, A.J.; Coffey, C.S.; Frost, A.; Barst, R.J.; Badesch, D.B.; Elliott, C.G.; et al. Predicting survival in pulmonary arterial hypertension: Insights from the Registry to Evaluate Early and Long-Term Pulmonary Arterial Hypertension Disease Management (REVEAL). Circulation 2010, 122, 164-172. [CrossRef]

129. Nickel, N.P.; Lichtinghagen, R.; Golpon, H.; Olsson, K.M.; Brand, K.; Welte, T.; Hoeper, M.M. Circulating levels of copeptin predict outcome in patients with pulmonary arterial hypertension. Respir. Res. 2013, 14, 130. [CrossRef]

130. Diehl, P.; Aleker, M.; Helbing, T.; Sossong, V.; Germann, M.; Sorichter, S.; Bode, C.; Moser, M. Increased platelet, leukocyte and endothelial microparticles predict enhanced coagulation and vascular inflammation in pulmonary hypertension. J. Thromb. Thrombolysis 2011, 31, 173-179. [CrossRef] 
131. Amabile, N.; Heiss, C.; Real, W.M.; Minasi, P.; McGlothlin, D.; Rame, E.J.; Grossman, W.; De Marco, T.; Yeghiazarians, Y. Circulating endothelial microparticle levels predict hemodynamic severity of pulmonary hypertension. Am. J. Respir. Crit. Care Med. 2008, 177, 1268-1275. [CrossRef] [PubMed]

132. Amabile, N.; Rautou, P.E.; Tedgui, A.; Boulanger, C.M. Microparticles: Key protagonists in cardiovascular disorders. Semin. Thromb. Hemost. 2010, 36, 907-916. [CrossRef] [PubMed]

133. Amabile, N.; Heiss, C.; Chang, V.; Angeli, F.S.; Damon, L.; Rame, E.J.; McGlothlin, D.; Grossman, W.; De Marco, T.; Yeghiazarians, Y. Increased CD62e $(+)$ endothelial microparticle levels predict poor outcome in pulmonary hypertension patients. J. Heart Lung Transplant. 2009, 28, 1081-1086. [CrossRef]

134. Gasecka, A.; Banaszkiewicz, M.; Nieuwland, R.; van der Pol, E.; Hajji, N.; Mutwil, H.; Rogula, S.; Rutkowska, W.; Pluta, K.; Eyileten, C.; et al. Prostacyclin Analogues Inhibit Platelet Reactivity, Extracellular Vesicle Release and Thrombus Formation in Patients with Pulmonary Arterial Hypertension. J. Clin. Med. 2021, 10, 1024. [CrossRef] [PubMed]

135. Larsen, C.M.; McCully, R.B.; Murphy, J.G.; Kushwaha, S.S.; Frantz, R.P.; Kane, G.C. Usefulness of High-Density Lipoprotein Cholesterol to Predict Survival in Pulmonary Arterial Hypertension. Am. J. Cardiol. 2016, 118, 292-297. [CrossRef] [PubMed]

136. Heresi, G.A.; Aytekin, M.; Newman, J.; DiDonato, J.; Dweik, R.A. Plasma levels of high-density lipoprotein cholesterol and outcomes in pulmonary arterial hypertension. Am. J. Respir. Crit. Care Med. 2010, 182, 661-668. [CrossRef]

137. Khirfan, G.; Tejwani, V.; Wang, X.; Li, M.; DiDonato, J.; Dweik, R.A.; Smedira, N.; Heresi, G.A. Plasma levels of high density lipoprotein cholesterol and outcomes in chronic thromboembolic pulmonary hypertension. PLoS ONE 2018, 13, e0197700. [CrossRef]

138. Takano, H.; Obata, J.E.; Kodama, Y.; Kitta, Y.; Nakamura, T.; Mende, A.; Kawabata, K.; Saito, Y.; Fujioka, D.; Kobayashi, T.; et al. Adiponectin is released from the heart in patients with heart failure. Int. J. Cardiol. 2009, 132, 221-226. [CrossRef]

139. Perrotta, F.; Nigro, E.; Mollica, M.; Costigliola, A.; D’Agnano, V.; Daniele, A.; Bianco, A.; Guerra, G. Pulmonary Hypertension and Obesity: Focus on Adiponectin. Int. J. Mol. Sci. 2019, 20, 912. [CrossRef]

140. Isobe, S.; Kataoka, M.; Kawakami, T.; Fukuda, K. Adiponectin in Chronic Thromboembolic Pulmonary Hypertension. Circ. J. 2018, 82, 1466-1468. [CrossRef]

141. Cracowski, J.L.; Degano, B.; Chabot, F.; Labarere, J.; Schwedhelm, E.; Monneret, D.; Iuliano, L.; Schwebel, C.; Chaouat, A.; Reynaud-Gaubert, M.; et al. Independent association of urinary F2-isoprostanes with survival in pulmonary arterial hypertension. Chest 2012, 142, 869-876. [CrossRef]

142. Zhang, R.; Sun, M.L.; Fan, Y.F.; Jiang, X.; Zhao, Q.H.; He, J.; Wang, L.; Shailendra, P.K.; Safdar, Z.; Jing, Z.C. Plasma 15-F2tisoprostane in idiopathic pulmonary arterial hypertension. Int. J. Cardiol. 2014, 175, 268-273. [CrossRef] [PubMed] 